\title{
USE OF GEOSPACIAL TECHNIQUES TO SUBSIDY THE CADASTRAL SURVEY OF ISOLATED PROPERTIES IN THE SOUTH-MATOGROSSEN PANTANAL AREA UNDER THE UNIVERSALIZATION OF ACCESS TO ELECTRICAL ENERGY
}

\author{
Fabiano Scheer HAINOSZ ${ }^{1}$ \\ Ellen Christine Prestes FERRONATO \\ Cresencio Silvio Segura SALAS \\ Cesar João ANDREAZZA ${ }^{1}$ \\ Giancarlo Covolo HECK ${ }^{1}$ \\ Letícia Helena Souza da SILVEIRA²
}

\begin{abstract}
The universal access to electricity is a very important issue for the country because it is directly related to economic and social development. In this context, Energisa Mato Grosso do Sul, which holds the power concession and distribution for the State of Mato Grosso do Sul, is looking for technical solutions economically viable to universalize the rural area at the Pantanal Sul-Matogrossense that presents challenges due to its extremely peculiar geographical, climatic and environmental characteristics. Therefore, this paper aims to subsidize the planning stages and cadastral survey of individual properties from the South Pantanal area, using geospatial techniques. These techniques include the cartographic mapping of the study area, the spatial analysis of georeferenced data and the development and customization of Geographical Information Systems (GIS). The results are almost 35 thousand linear kilometers of access roads and more than 16 thousand buildings have been mapped, of which at least $29 \%$ are still not served by the electricity distribution network. Systems to subsidize the navigation and cadastre the isolated properties were also customized and developed. All of these inputs that allowed the planning and survey steps in the field are carried out with greater efficiency and assertiveness.
\end{abstract}

Key words: Cartography mapping. Geoprocessing. GIS. Isolated áreas. Pantanal.

\footnotetext{
1 Institutos Lactec, Rodovia BR116 km 98, no 8813, Jardim das Américas, Caixa Postal 19067, CEP 81531-980, Curitiba-PR, Brasil. E-mails: fabiano.h@lactec.org.br; ellen.ferronato@lactec.org.br; silvio.salas@lactec.org.br; cesar.andreazza@lactec.org.br; giancarlo.c@lactec.org.br

2 Energisa, Av. dos Astronautas 1758, Caixa Postal 515, CEP 12201-970, São José dos CamposSP, Brasil. E-mail: leticia.silveira@energisa.com.br
} 


\section{Resumo}

\section{Uso de técnicas geoespaciais para subsidiar o levantamento cadastral de propriedades isoladas na área do Pantanal Sul-Matogrossense no âmbito da universalização de acesso à energia elétrica}

A universalização do acesso à energia elétrica é um tema de grande relevância para o país porque está diretamente relacionado ao desenvolvimento econômico-social. Nesse contexto, a Energisa Mato Grosso do Sul, que detém a concessão de distribuição de energia deste Estado, está em busca de soluções técnicas, viáveis economicamente, para universalizar a área rural do Pantanal Sul-Matogrossense, que apresenta desafios devido às suas características geográficas, climáticas e ambientais extremamente peculiares. Portanto, este trabalho se propõe a criar subsídios e ferramentas para facilitar e melhorar as etapas de planejamento e levantamento cadastral das propriedades isoladas no Pantanal Sul-Matogrossense, através do uso de técnicas geoespaciais. Essas técnicas contemplam o mapeamento cartográfico da área de estudo, a análise espacial de dados georreferenciados e o desenvolvimento e customização de Sistemas de Informações Geográficas (SIG). Como resultados foram mapeados quase $35 \mathrm{mil} \mathrm{km}$ lineares de vias de acesso e mais de 16 mil edificações, das quais, pelo menos $29 \%$ ainda não são atendidas pela rede de distribuição de energia elétrica. Também foram customizados e desenvolvidos sistemas para subsidiar a navegação e cadastro das propriedades isoladas. Todos esses insumos permitiram que as etapas de planejamento e levantamento em campo fossem realizadas com maior eficiência e assertividade.

Palavras-chave: Mapeamento cartográfico. Geoprocessamento. SIG. Áreas isoladas. Pantanal.

\section{INTRODUCTION}

Universal access to electricity is a relevant topic for the country, which is one of the Federal Government concerns towards the interior development. Data drawn from statistics of the Census 2000 (Population Census 2000, 2000) and the Ministry of Mines and Energy (MME) show the relationship between the lack of electricity supply structure and the social exclusion of communities, presenting the difficulties of economic and social development of these regions. MME in a study published in 2003, 27.6\% of the Brazilian Midwest rural population had no access to electricity, which corresponds to about 370,000 people. The weakness of public policies for the interior development over the years promoted a migratory flow towards capitals and large urban centers. According to the Census 2010 (DEMOGRAPHIC CENSUS 2010, 2011), the Brazilian population exceeded 200 million inhabitants $(202,768,562)$, of which 48.3 million live in the capitals, corresponding to $23.8 \%$ of the total population. This fact further increases the inequality between the capitals and the interior, in addition to overload the existing infrastructure of large urban centers and disrupt the planning of the resources to be invested in each of the country areas.

In the specific case of isolated regions of Pantanal in Mato Grosso do Sul, the viability of the electricity supply to the properties located in this region becomes complicated not only because of aspects of infrastructure investment, but also because of its specific features: large areas of environmental preservation and seasonal flooding.

In this context, prior to any planning aimed at supplying and distributing power to isolated regions, obtaining a complete and up-to-date georeferenced database is critical. 
Given the dimensions of the Pantanal area in Mato Grosso do Sul, measured by Silva and Abdon (1998, p. 1707) in 89,318,000 square kilometers, study area of this work and the difficulty in obtaining updated spatial data and appropriate scale (equal to or greater than $1: 50,000$ ) for studies, planning and surveys in the field, one of the solutions is to develop a cartographic base, from the use of satellite images, defining the layers of information that require greater detail and updating, and consolidating this base with other compatible and existing ones.

Another relevant issue to be considered is the provision of appropriate tools for the cadastral survey properties of the isolated, eg, Geographic Information Systems (GIS) navigation and registration, so that the work can be performed with speed, completeness, coordination, and even greater security.

This work is inserted in a broader project called "Development of electric power supply to critical methodology isolated systems in the Pantanal of Mato Grosso do Sul" of the Energisa Mato Grosso do Sul, which is being conducted with the support of the Institutes LACTEC and Calden Consultoria de Engenaria Ltda under the Research and Development program of ANEEL.

\section{OBJECTIVE}

The work aims to create subsidies and tools to facilitate and improve the planning stages and cadastral survey of isolated properties in the Pantanal of Mato Grosso do Sul, through the use of geospatial techniques.

\section{MATERIALS AND METHODS}

\section{Study area}

The study area corresponds to the Pantanal of Mato Grosso do Sul covering the municipalities of Corumbá, Aquidauana, Miranda, Coxim, Rio Verde de Mato Grosso, Ladário and Porto Murtinho. The study area Illustrated by following the red in Figure 1.

Considering that the focus of this work is the survey of the isolated properties, the areas corresponding to the municipalities urban limits of Corumbá, Ladário and Porto Murtinho were disregarded. 


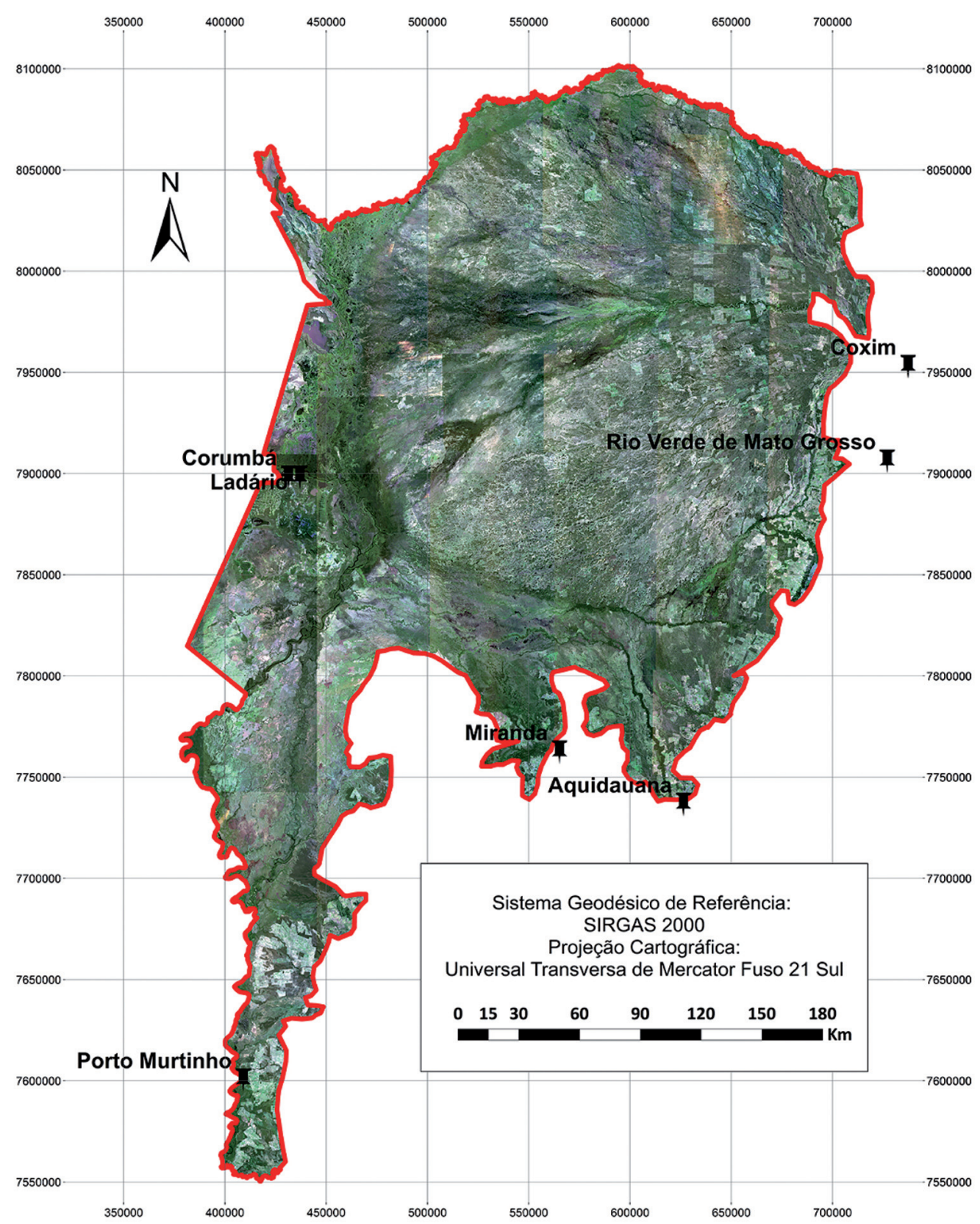

Figure 1 - Study area of the Pantanal of Mato Grosso do Sul 


\section{METHODOLOGICAL PROCEDURES}

\section{Acquisition of orbital images and spatial analyzes}

Given the unavailability of essential map data updated to the study area it was necessary to acquire recent catalog orbital images (acquisition period less than 1 year) and with $0 \%$ cloud incidence, so that buildings and road system could be mapped. Based on these conditions for the acquisition of orbital images, it was opted for the satellite data purchase SPOT6 acquired in the period from June to August 2015.

Images from SPOT6 have a spatial resolution of six meters for the multispectral bands RGB and 1.5 meters for panchromatic band. However, due to the large difference in cost (approximately 3 times higher) of color images merged with the panchromatic band, it was decided to purchase only the composite multispectral bands.

All images were acquired from the georeferenced satellite orbital parameters and orthorectified from the digital elevation model SRTM (Shuttle Radar Topography Mission). The final scale cartographic scheduled for mapping carried out based on these ortho images, it is equal to 1:50 .000.

Given that not all the properties located in the study area are isolated without access to electricity distribution network, some spatial analyzes were performed in order to identify just the buildings that in fact need to be visited and registered in the field. To perform these analyzes the buildings were used as input data, mapped through the ortho orbital images, and spatial data from the existing electricity distribution network (vectors of distribution lines and location of transformers provided by the electric utility Energisa - EMS). These spatial analyzes were carried out with the help of ArcGIS software (ESRI, 2016).

\section{NAVIGATION AND REGISTRATION SYSTEMS OF ISOLATED PROPERTIES}

The registration of isolated properties consists of the collection of information in the field of buildings not served by the existing electricity grid for the Pantanal of Mato Grosso do Sul area, considering the general characteristics of the entire area and its particularities.

Prior to the start of the field survey, detailed planning of which properties will need to be raised is required, and how the teams will move to them. With this approach, this work also includes the development and/or customization of information systems for navigation and registration purposes, both shipped in a single mobile device (Tablet).

For the spatial orientation of the field teams, an important issue considered was the low availability and precariousness of internet connection in the study area (ANATEL, 2015). In this way, the use of navigation applications that worked disconnected from the internet was imperative.

At first, the development of a specific application was considered, but the time of analysis and development in relation to the project schedule made this option impracticable. Thus, once it was established that the field teams would work with mobile equipment and Android operating system on board, a search was made for software that had the disconnected functionality of the internet, with support for GNSS (Global Navigation Satellite System) navigation, storage routing, point of interest registration and view of point, line, polygon and geo-referenced images. One of the 
most complete applications found was Locus Map Pro (Figure 2) in the Google Play app store.

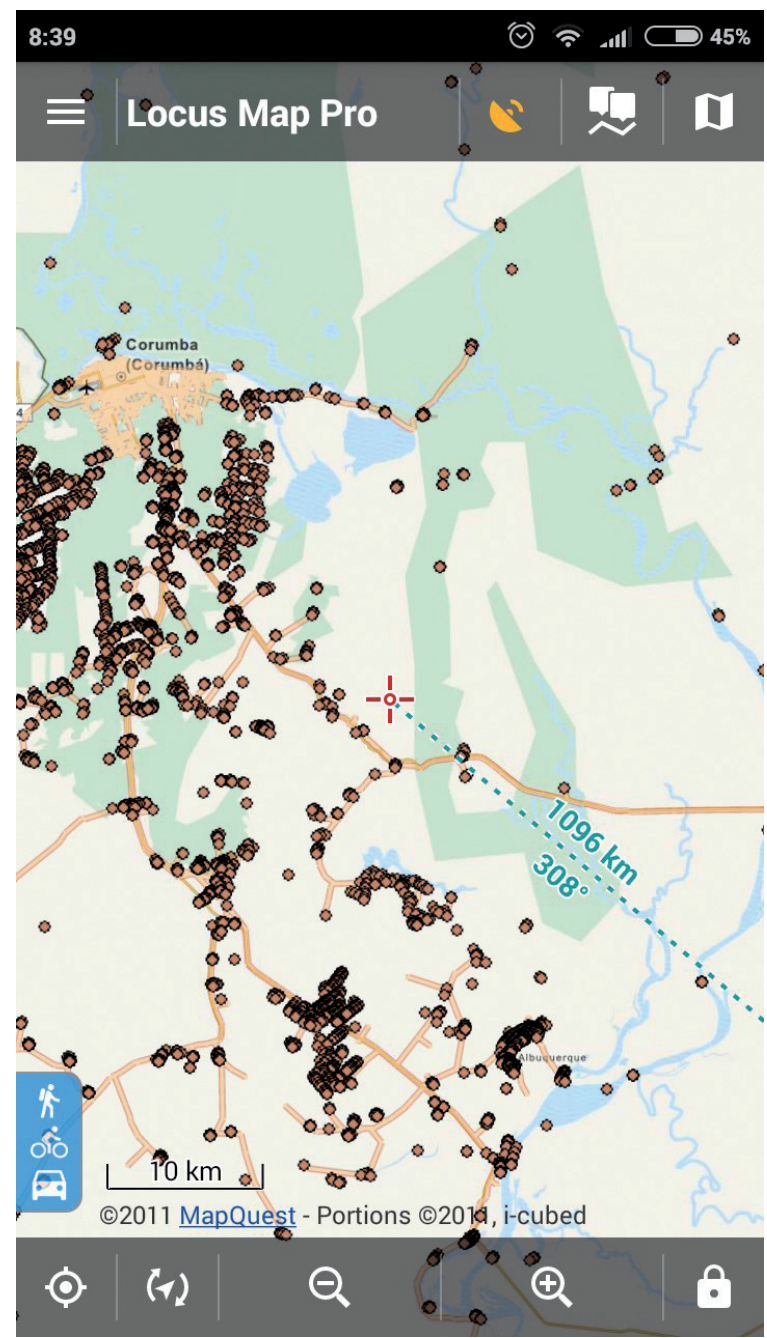

Figure 2 - Locus Map Pro application interface

A feature of Locus Map Pro is mbtiles format file support, which is a file type that basically stores images trimmed as tiles at various zoom levels, which allows to zoom in and out of the map within the application. Zoom levels have been set with the restriction of generating very large files ( $>1 \mathrm{~Gb}$ ), due to the mobile device memory and processing limitations. 
The TileMill software was used to obtain the mbtiles files, which is shown in figure 3 .

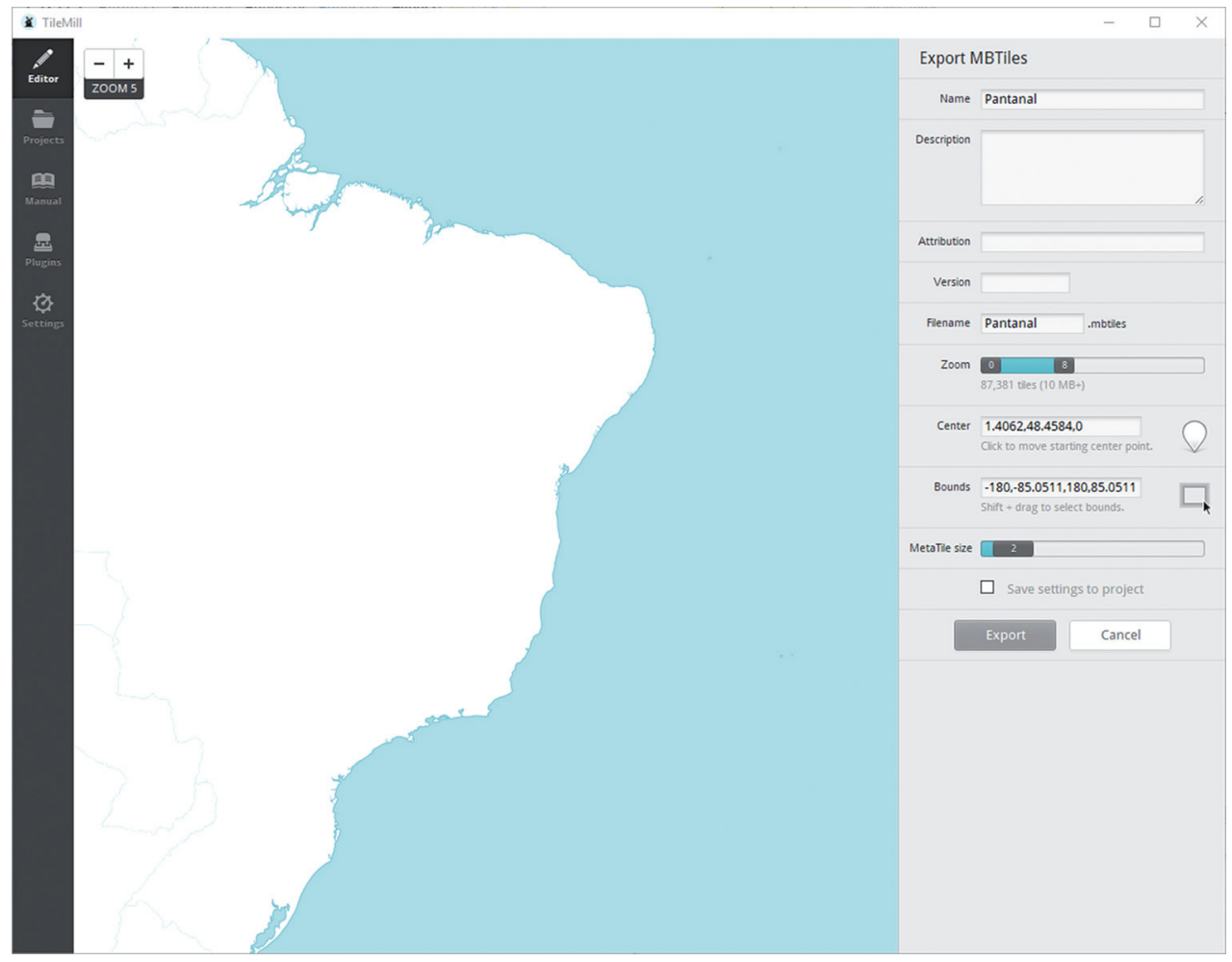

Figure 3 - TileMill software interface

A Garmin Etrex 20x GNSS handheld device was also available as a backup system in the event of a mobile device failure.

In order to carry out the interviews for the registration of the properties, considering the many particularities, a computer system was developed, consisting of a mobile module and a WEB module, from registration and transmission of field data to the availability of queries and reports of internet monitoring. This system is based on the Python programming language and PostgreSQL database and is presented and further detailed in the sequence.

\section{RESULTS AND DISCUSSION}

\section{Mapping}

As mentioned before, the pre-defined layers to be vectored based on the SPOT6 orbital images were the road system and the buildings. Conventionally, for the 1:50,000 
scale, isolated buildings are not represented, but their identification was necessary in order to subsidize all field planning, studies and surveys. Thus, in view of the difficulties observed in the mapping of small buildings (e.g. less than 300 square meters of area) from SPOT6 orthoimages with GSD of 6 meters, the use of complementary data such as Google Earth Pro and ArcGIS Online, was required. Other layers of information were also considered for the interpretation of the images, such as the limits of the rural properties provided by INCRA of Mato Grosso do Sul.

Figure 4 shows an example of the same area represented by the SPOT 6 images (GSD: 6 meters) and the Google Earth Pro and ArcGIS Online database images.

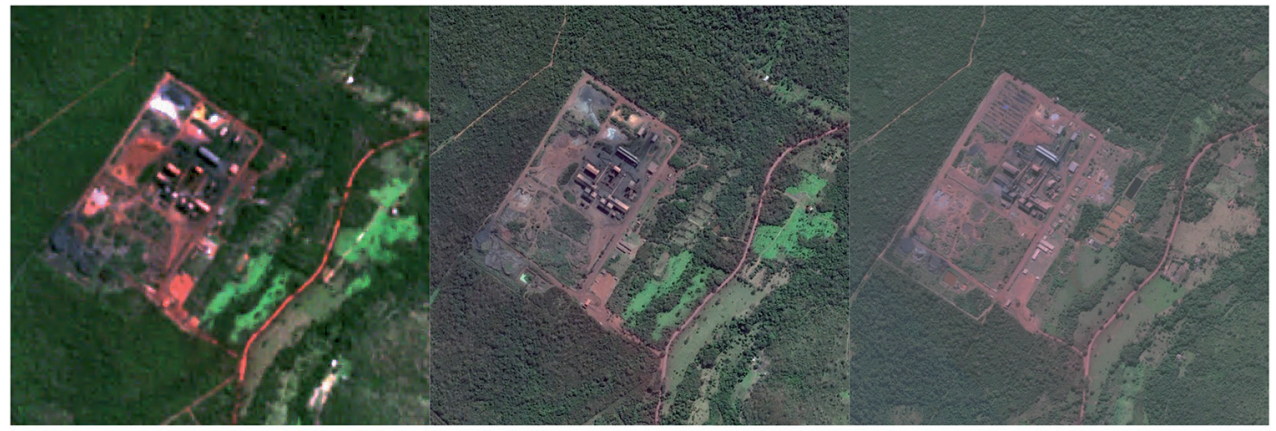

\title{
Spot 6\&7 Google Earth ArcGIS Online
}

\author{
Figure 4 - Sample images: SPOT, Google Earth \\ and ArcGIS Online databases
}

It is observed that the images of Google Earth Pro and ArcGIS Online present for the area indicated in figure 4 a spatial resolution more appropriate for the identification of buildings, but data of these sources are not homogeneous for the whole area of study and are outdated in some locations (more than 10 years of lag). In this way, it was chosen to work with SPOT6 orthoimages as the main reference to clarify any doubts from other sources.

The result, at the end of the buildings mapping and road system, after deducting the urban limits of the municipalities of Corumbá, Ladário and Porto Murtinho, was 16,656 buildings and 34,917 linear kilometers of road system mapped. Figure 5 shows the complete mapping performed in the study area. 


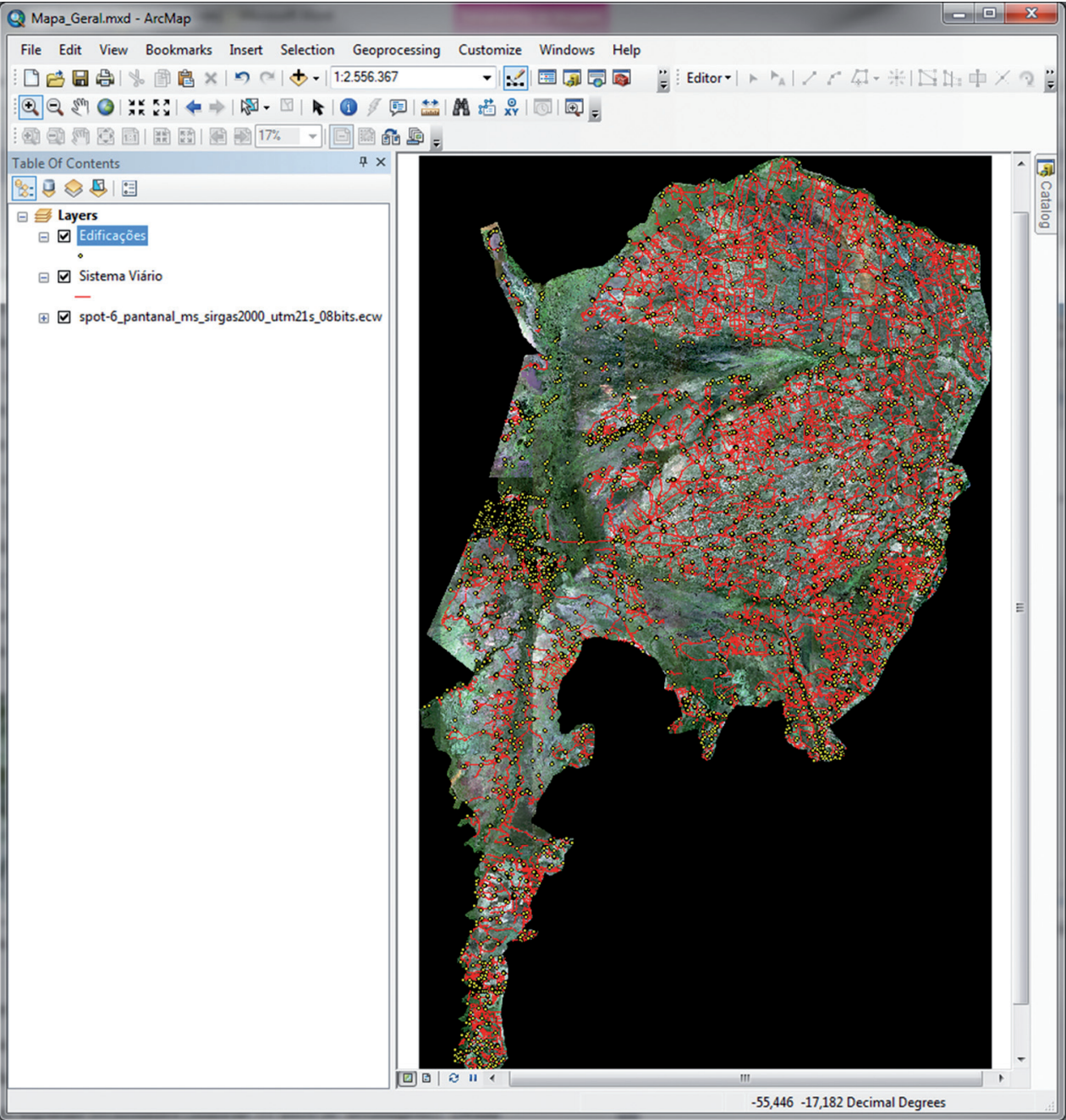

Figure 5 - Buildings and road system mapped in the study area

\section{SCENARIO ANALYSIS AND TOTALIZATION OF ISOLATED PROPERTIES}

Using the data layer of the buildings mapped through the orbital images and the georeferenced information of the distribution network and transformers currently in the currently study area, some spatial analysis were done in ArcGIS software (ESRI, 2016) to determine which buildings were actually isolated and would need to be registered in the field. In all, 5 different scenarios were considered, which are shown in Table 1. 
Table 1 - Scenarios of buildings served and not served by the energy distribution network

\begin{tabular}{ccccc}
\hline Scenario & $\begin{array}{c}\text { Proximity of } \\
\text { the network }\end{array}$ & $\begin{array}{c}\text { Buildings } \\
\text { serviced }\end{array}$ & $\begin{array}{c}\text { Buildings } \\
\text { missed }\end{array}$ & $\%$ not met \\
\hline 1 & 100 meters & 6,981 & 9,675 & $58.1 \%$ \\
2 & 500 meters & 10,880 & 5,776 & $34.7 \%$ \\
3 & 1,000 meters & 11,123 & 5,533 & $33.2 \%$ \\
4 & 2,000 meters & 11,285 & 5,371 & $32.2 \%$ \\
5 & 5,000 meters & 11,721 & 4,935 & $29.6 \%$ \\
\hline
\end{tabular}

In Figure 6 a location with the buildings selected for the 500 meters scenario around the distribution network is illustrated.

It is observed that depending on the scenario considered, the number of buildings served by the existing power distribution network suffers a substantial variation, which can result in a later work of cadastral survey in a much larger field depending on the criteria adopted. 


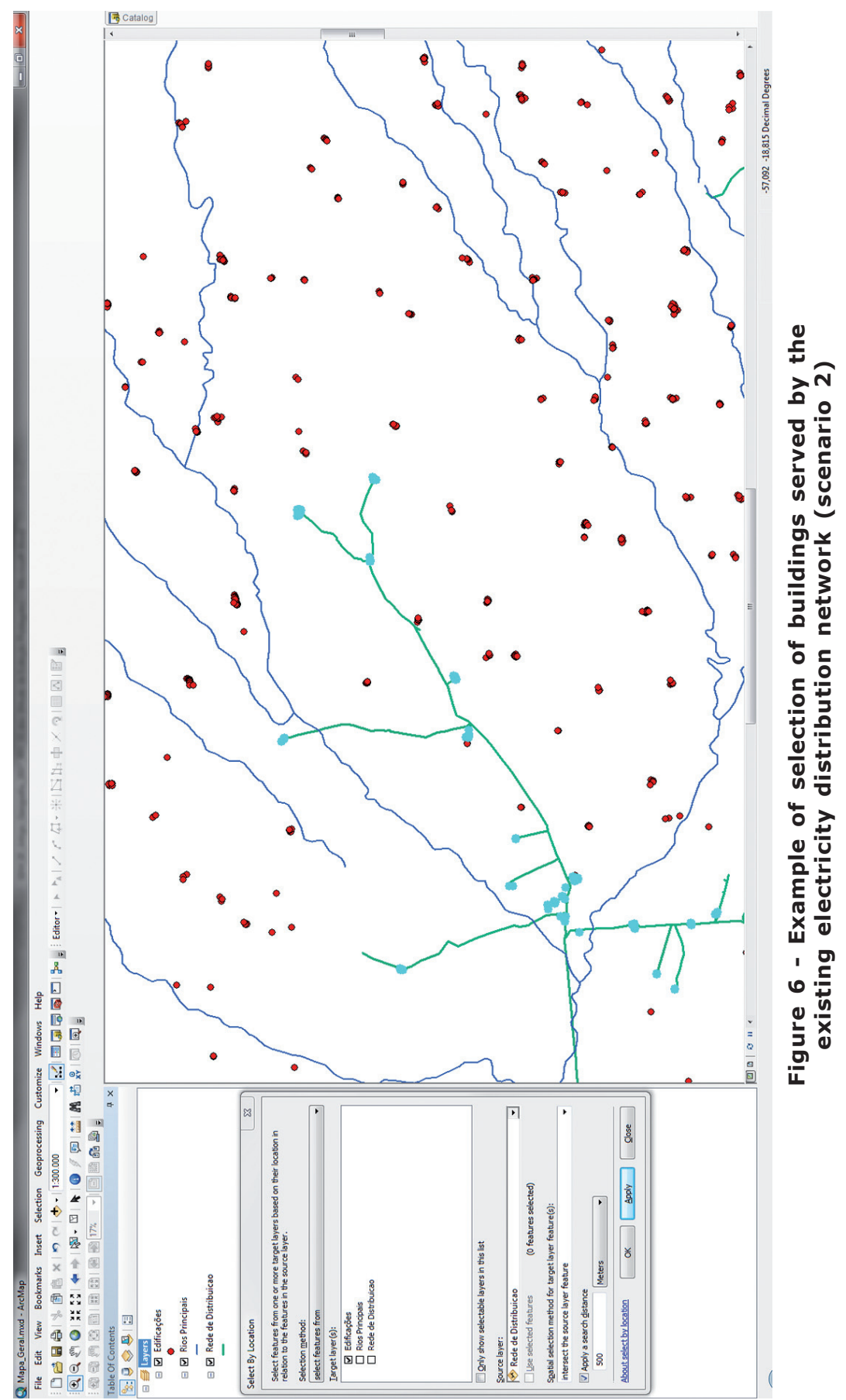




\section{INFORMATION SYSTEM FOR THE PROPERTY REGISTRATION}

To assist in the process of data collection, a computer system was developed, consisting of a mobile module and a WEB module, which cover everything from the registration and transmission of field data to the availability of consultations and monitoring reports through the internet.

The mobile module was developed in the form of an application for the Android platform and had its screens designed for better display on tablet-like devices with screens between 7 and 8 inches in size. Figure 7 shows some of the screens of the mobile module.

With the use of the mobile module, field registrars can easily collect property information, including data on geographic location, construction, access, economic activities and production, possessions and habits, demands on energy resources, social information, as well as performing the photographic record. To cover this range of data, the research form has more than 40 screens of forms to fill, being the complete registration in an average time of 18 minutes.

All information recorded on the mobile device (Tablet) is stored in the device's internal memory and on a removable memory card in the form of a backup copy, to prevent loss of stored information in case of damage to the device. Further, the mobile module has the functionality of transmitting all the data registered to a central server, whenever there is internet access available.

On the other hand, the WEB module, is a web application accessible via internet, developed in Python programming language and with access to the database (PostgreSQL) that receives the information transmitted by the field devices. This module is responsible for providing queries and reports for the monitoring of activities in real time.

One of the main functionalities of the WEB module is the georeferenced search query. This query displays the geographic location of the registered properties, which can be filtered by the search number, by field team, or by a date range.

The information can be viewed in simplified format, for example, by clicking once on one of the markers (flags) displayed on the map or in full format with the double-click on the appropriate marker. The complete information is displayed in an auxiliary window in the browser and includes all the photos collected during the field registration. Figure 8 illustrates these single and double click features, respectively.

In addition, the WEB module allows the issuance of several reports to assist the process of monitoring the field work, as well as the export of all data recorded for use in other software. 

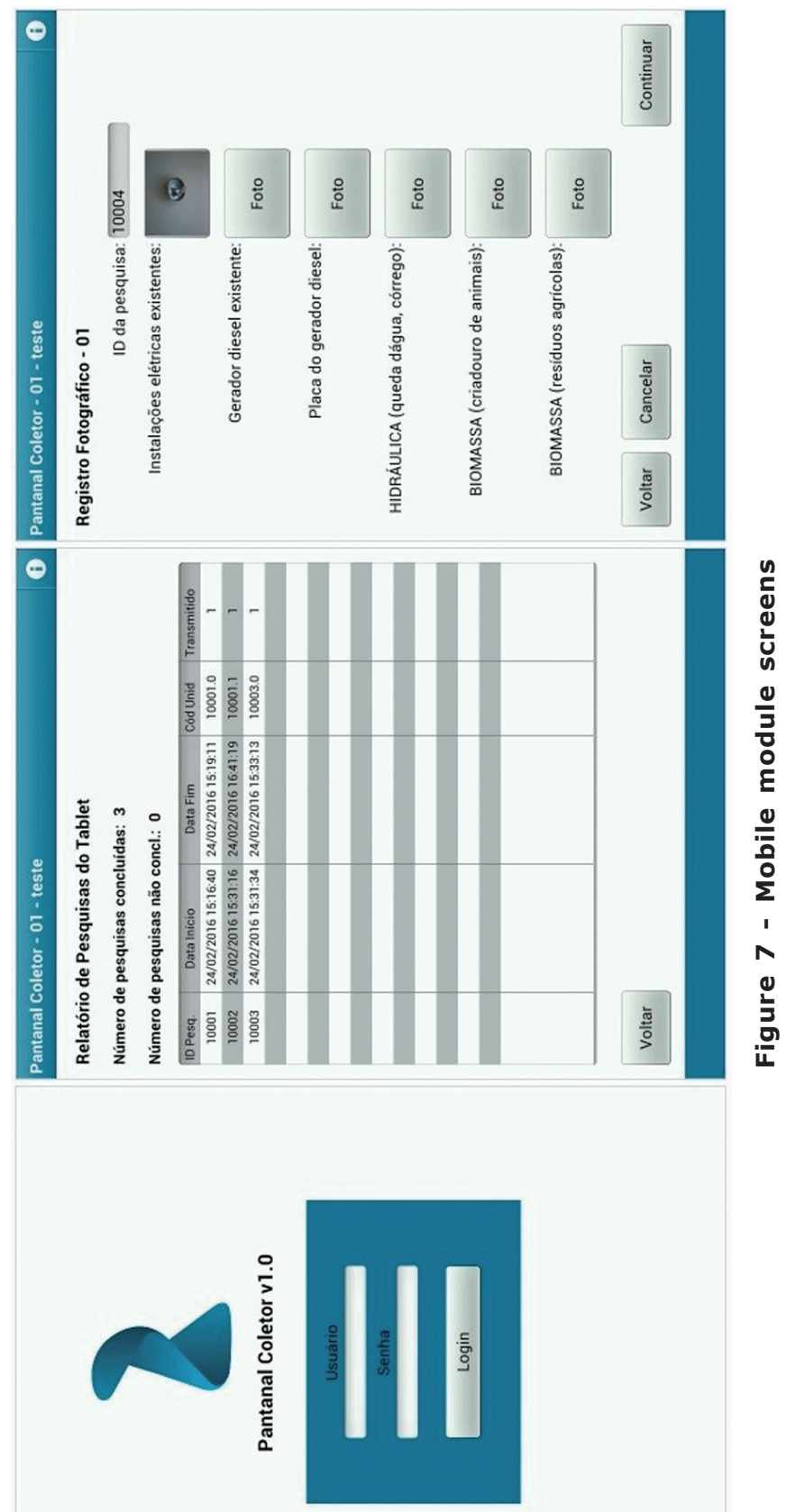


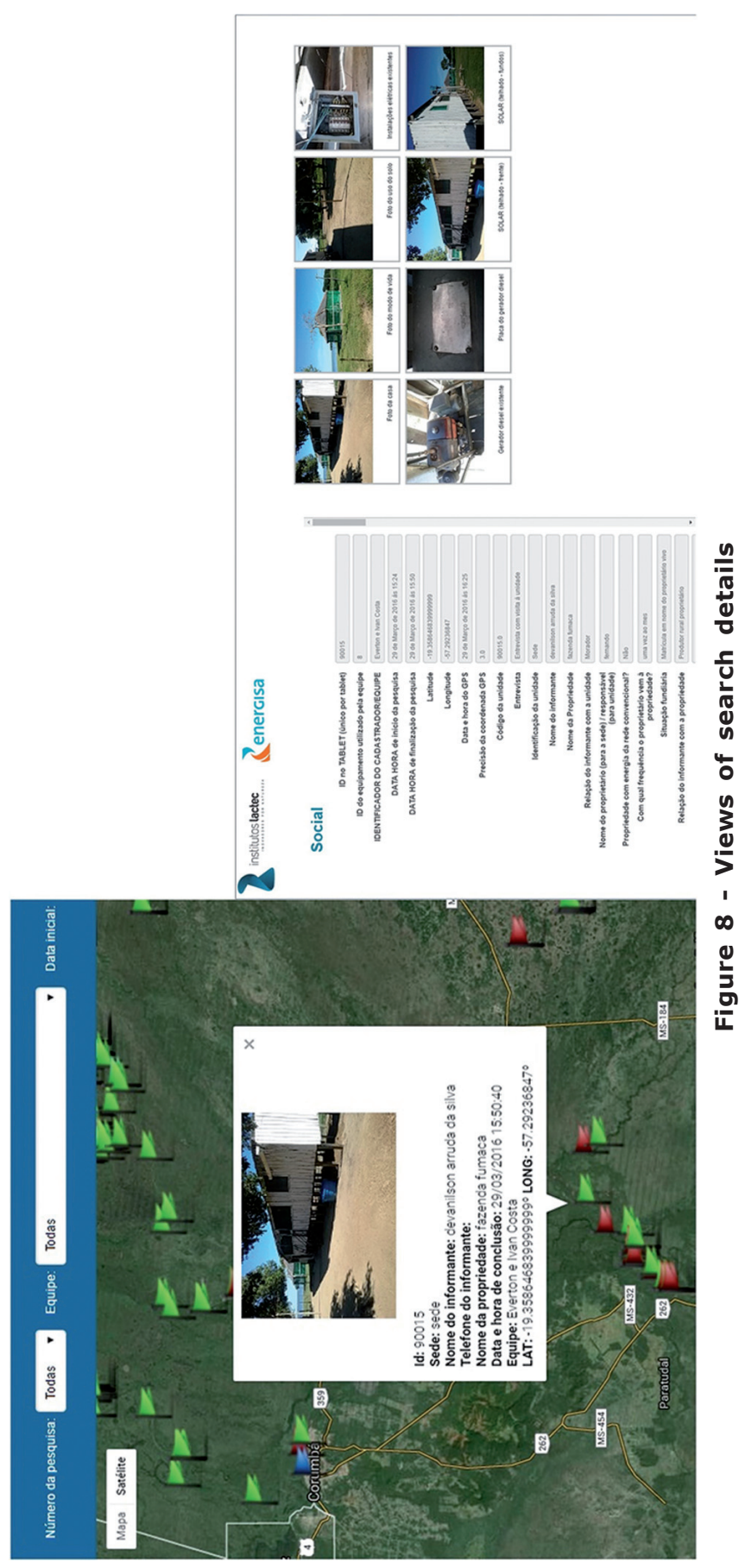




\section{CONCLUSIONS}

The use of SPOT6 orbital images was not satisfactory for mapping small and medium sized buildings (less than $300 \mathrm{~m}^{2}$ in area), but the combination of these with free images, such as those available by ArcGIS Online and Google Earth Pro, allowed a better interpretation of area and identification of buildings.

Despite being considered an isolated region, it was possible to observe that the rural area of the Pantanal of Mato Grosso do Sul has a substantial amount of roads and accesses (more than 34 thousand linear kilometers in length). This observation allows the logistic planning of field surveys to be carried out, predominantly, considering the use of land transport vehicles.

Spatial proximity analyzes of the mapped buildings of the existing power distribution network were essential to avoid unnecessary field surveys. From the presented scenarios it is observed that, if this spatial analysis were not performed, the universe of buildings to be registered could be tripled, compromising the term and available resources for the later stage of cadastral survey.

Considering the high amount of information to be registered for each isolated property, the use of the embedded system in mobile devices was essential for agility and standardization in the registration of information. Other benefits of the registration system were autonomous association of information to be geo-referenced coordinates, if the spatial locations of isolated properties, and the record of the time shifts and journeys are made by teams in the field.

The WEB module of the registration system is allowed, once the data collected in the mobile module are transmitted automatically when the device is connected to the internet network the daily monitoring of surveys in the field. This enables project coordinators and / or project managers to monitor the progress of work and, if necessary, take mitigating measures to avoid delays in the project schedule.

Finally, with this work, the advantages of using geospatial techniques were verified in order to guarantee efficiency and assertiveness in any field surveys, especially in special areas such as the Pantanal.

\section{ACKNOWLEDGMENTS}

The authors thank the ANEEL R\&D Program for the availability of financial resources to carry out this work.

\section{REFERENCES}

ANATEL. National Telecommunications Agency. Mobile Phone Map. Available at: <http://gatewaysiec.anatel.gov.br/mobileanatel/>. Accessed on: 2015, December 5 ANDROID. Platform mobile application development. Available at: <https:// developer.android.com>. Accessed on: 2016, February 10

ESRI. ArcGIS Desktop version 10.2. Esri Inc. 2016. 
DEMOGRAPHIC CENSUS 2000. Rio de Janeiro: IBGE, 2000. ISSN 0104-3145.

DEMOGRAPHIC CENSUS 2010. Rio de Janeiro: IBGE, 2011. ISSN - 1676-4935 (CDROM). ISSN - 0104-3145 (printed version).

GOOGLE PLAY. Locus Mapa Pro - Outdoor GPS. Available at: <https:// play.google.com/store/apps/details?id=menion. android.locus.pro>. Accessed on: 2015, December 15

MAPBOX. Create beautiful interactive maps. Available at: <https:// www.mapbox.com/tilemill/>. Accessed on: 2015, December 18

MBTILES. MBTiles Specification. Available at: <https://github.com/mapbox/mbtilesspec>. Accessed on: 2015, December 18

MME. Ministry of Mines and Energy. Light for All Program. Year of publication: 2003. Brasília. Available at: <http://www.mme.gov.br/luzparatodos>. Accessed on: 2015, November 15

POSTGRESQL. Open source object-relational database management system. Available at: <http://www.postgresql.org.br/>. Accessed on: 2016, February 10

PYTHON. Programming language for system integration. Available at: <https:/ /www.python.org/>. Accessed on: 2016, March 5

SILVA, J. S. V.; ABDON, M. M. Delimitation of the Brazilian Pantanal and its subregions. Brazilian Agriculture and Livestock Research, v. 33, special number, p. 1707, 1998. 